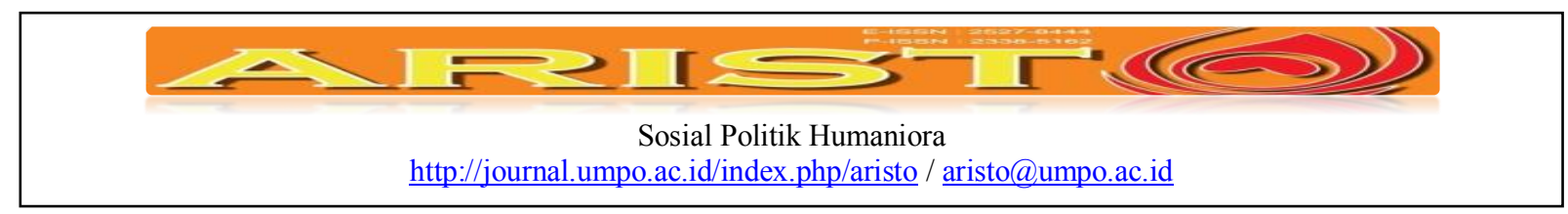

\title{
Efektivitas dana desa untuk pengembangan potensi ekonomi berbasis partisipasi masyarakat di Desa Bangunjiwo
}

\author{
Muhammad Eko Atmojo, Helen Dian Fridayani, Aulia Nur Kasiwi, Mardha Adhi Pratama \\ Program Studi Ilmu Pemerintahan, FISIP Univeristas Muhammadiyah Yogyakarta \\ muhammadekoatmojo@yahoo.com
}

\begin{abstract}
Community empowerment is part of economic development in Indonesia. As one of strategy to empower the community is by establishing the rulal allocation fund by government as mentioned on "Undang-Undang Nomor 6 Tahun 2014" about rural. Therefore, the "Undang-Undang Nomor 6 Tahun 2014" came along with rural allocation fund hopefully might be able to increase the participation of rural community to developing economic condition in order to establish community prosperity. This research used the qualitative method, obesrvation, interview, also documentation. This research aim to analyze the effectiveness of rural fund allocation toward society empowerment, particularly in economic aspect based on community participation in Bangunjiwo Village. Therefore, this research shows that first, the utilization rural fund allocation is most effective for development of economic potential. Second, Bangujiwo Village provider the training for community's activity ini order to increasing the economic potential. The last, the mainly economic potential in Bangujiwo Village is called "Kajigelem".

Keywords: Community Participation, Community Empowerment, Economic Potential and Rural Allocation Fund.
\end{abstract}

\begin{abstract}
Abstrak
Pemberdayaan masyarakat merupakan bagian dari pembangunan ekonomi di Indonesia. Sebagai salah satu strategi untuk memberdayakan masyarakat adalah dengan adanya alokasi dana desa oleh pemerintah sebagaimana yang telah dituangkan pada Undang-Undang nomor 6 Tahun 2014 tentang Desa. Oleh karena itu, Undang-Undang nomor 6 Tahun 2014 yang didalamnya memuat adanya dana alokasi desa diharapkan dapat meningkatkan partisipasi masyaraka desa dengan mengembangkan ekonomi dalam rangka membangun kesejahteraan masyarakat. Penelitian ini menggunakan metodologi kualitatif, dengan metode observasi, wawancara serta dokumentasi. Tujuan dari penelitian ini adalah untuk mengetahui dan menganalisis efektivitas dari alokasi dana desa menuju pembangunan masyarakat khususnya pada aspek ekonomi berbasis partisipasi masyarakat di Bangunjiwo. Hasil penelitian ini menyatakan bahwa penggunaan alokasi dana desa efektif untuk mengembangkan potensi ekonomi. Kedua, Desa Bangunjiwo menyediaka pelatihan khusus untuk kegiatan masyarakat dalam rangka mendorong tumbuhnya potensi ekonomi. Terakhir, potensi ekonomi utama Desa Bangunjiwo disebut "Kajigelem".
\end{abstract}

Kata Kunci: Partisipasi Masyarakat, Pemberdayaan Masyarakat, Potensi Ekonomi dan Alokasi Dana Desa. 


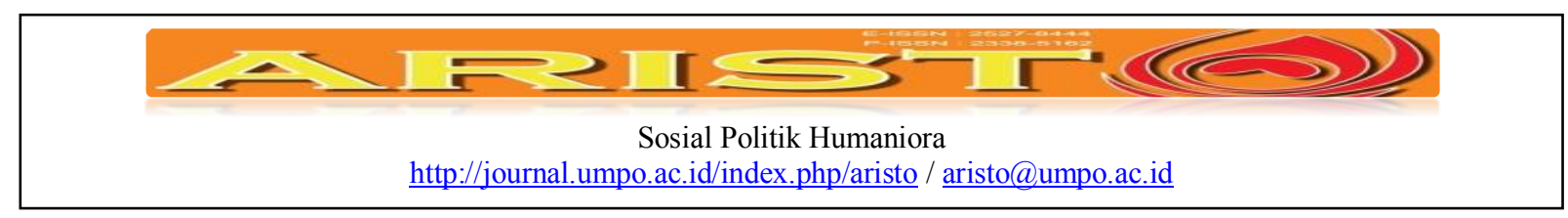
Submite
: 14 Nov 2016
Review
: 20 Nov 2016
Accepted
: 01 Jan 2017
Surel Corespondensi : jovani.audra@gmail.com/adamhilman@umpo.ac.id

\section{Pendahuluan}

Kelancaran pembangunan nasional diawali dari pembangunan ditingkat yang paling bawah yaitu pembangunan desa. Namun pada pelaksanaan pembangunan nasional masih ada beberapa masalah pokok pembangunan seperti ketimpangan pembangunan ekonomi antara desa dan kota di Indonesia. Berdasarkan pernyataan Institute for Development of Economics and Finance (INDEF) bahwa belum meratanya pertumbuhan ekonomi karena adanya ketimpangan pembangunan infrastruktur, ketimpangan kualitas SDM, dan ketimpangan sumber energi yang masih terpusat. ${ }^{1}$ Tidak meratanya pembangunan akan berdampak pada tingkat kemiskinan di Indonesia. Berdasarkan data dari BPS jumlah penduduk miskin pada tahun 2012 dibagi menjadi dua yaitu, angka kemiskinan penduduk di kota sebesar $8.60 \%$ sedangkan angka kemiskinan penduduk di pedesaan sebesar $14.70 \%{ }^{2}$ Menanggapi permasalahan tersebut, strategi pemerintah untuk mengatasi ketimpangan pembangunan yaitu dengan melaksanakan pembangunan nasional yang menaruh perhatian besar terhadap pembangunan desa. ${ }^{3}$

Pembangunan desa mempunyai peranan yang sangat penting dan strategis dalam rangka pembangunan nasional dan pembangunan daerah, karena di dalamnya terkandung unsur pemerataan pembangunan dan hasil - hasilnya bisa menyentuh secara langsung kepentingan sebagian besar masyarakat yang bermukim di perdesaan dalam rangka upaya meningkatkan kesejahteraan. ${ }^{4}$ Pembangunan yang bisa dilakukan di daerah pedesaan adalah

1 Pertumbuhan Ekonomi tak Merata, Pengamat: Akibat Ketimpangan Infrastruktur diakses dari http:/www.republika.co.id/berita/ekonomi/makro/15/05/07/nny3e7-pertumbuhan-ekonomi-tak-merata-pengamatakibat-ketimpangan-infrastruktur pada tanggal 17 April 2017, pukul 09.30 WIB.

${ }^{2}$ Badan Pusat Statistik. 2013. Jumlah Penduduk Miskin dan Prosentase Penduduk Miskin di Indonesia. Badan Pusat Statistik. http://www.bps.go.id/tab_sub/view.php?kat=1\&tabel=1\&daftar=1\&id_subyek=23\&notab=1/ diakses pada 20 Februari 2017, pukul 16.35 WIB.

${ }^{3}$ ChandraKusuma Putra dkk. (2013). Pengelolaan Alokasi Dana Desa Dalam Pemberdayaan Masyarakat Desa (Studi Pada Desa Wonorejo Kecamatan Singosari Kabupaten Malang). Jurnal Administrasi Publik Vol. 1 No 6.

$$
{ }^{4} \underline{\text { IBID. }}
$$




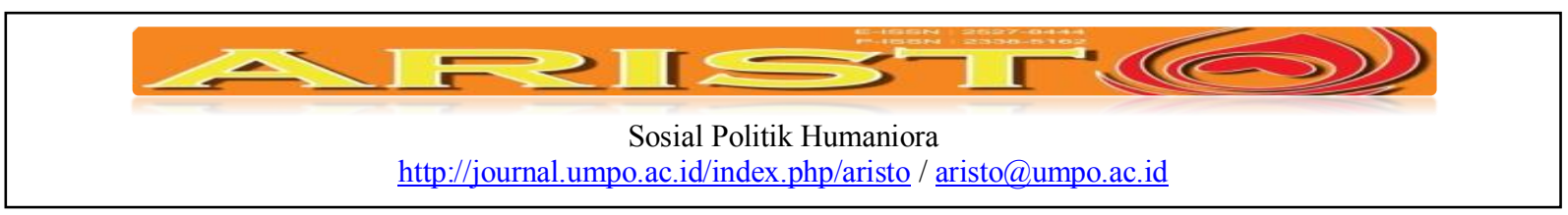

dengan memberdayakan masyarakat serta pengembangan ekonomi masyarakat. Pembangunan melalui pemberdayaan dan pengembangan ekonomi masyarakat sangat efektif untuk peningkatan kesejahteraan masyarakat desa, terutama dengan memunculkan potensi ekonomi berbasis masyarakat. Potensi ekonomi saat ini sangat menjadi incaran suatu daerah untuk dapat membangun dan membangkitkan partisipatif masyarakat. Dukungan pemerintah terhadap peningkatan ekonomi di masyarakat desa pun sudah diwujudkan dalam implementasinya hal ini terkait dengan Undang-Undang Nomor 6 Tahun 2014 Tentang Desa yang merupakan desentralisasi birokrasi yang mengalami perubahan yang cukup baik agar kebijakan-kebijakan yang dibuat akan cepat tersalurkan dan membantu mengurangi masalah-masalah yang ada.

Pembangunan di tingkat desa sudah sejak lama digulirkan dengan adanya bantuan dari pemerintah yatu dengan alokasi dana desa yang diambil dari 10\% dana APBD, sejak terbitnya Undang-Undang Nomer 6 tahun 2014 tentang Desa maka pembangunan desa bisa dilakukan dengan dana desa. Dari jumlah total anggaan dana desa, Daerah Istimewa Yogyakarta memiliki total dana desa sebesar 112,68 miliar untuk 438 desanya. ${ }^{5}$ Hal ini merupakan jumlah yang tidak sedikit untuk sebuah desa, dimana desa harus bisa mengelola dengan baik. Namun sesuai dengan amanat Permendes yang menyebutkan bahwa dana desa diprioritaskan untuk membiayai belanja pembangunan dan pemberdayaan masyarakat desa. ${ }^{6}$ Dengan adanya dana desa ini maka setiap desa wajib melakukan pembangunan desa, terutama dalam bidang pengembangan potensi ekonomi lokal. ${ }^{7}$ Mengingat dana yang diberikan begitu besar, maka harus dikelola dengan sebaik mungkin. Yang mana dalam pelaksanaan program pembangunan desa dengan dana desa juga harus melibatkan masyarakat, sehingga masyarakat merasakan kemajuan desa yang dikelola dengan dana desa. Demi terciptanya desa mandiri maka peningkatan potensi ekonomi desa yang berbasis masyarkat harus di munculkan. Dalam peningkatan ekonomi desa maka diperlukan pelibatan masyarakat sekitar terutama dalam pembangunan desa maupun pemberdayaan masyarakat desa. Seperti halnya Desa Bangunjiwo yang menjadi salah satu desa untuk mengembangkan potensi ekonomi berbasis masyarakat. Bangujiwo merupakan persatuan dari

${ }^{5}$ Biro Analisa Anggaran dan Pelaksanaan APBN - SETJEN DPR RI. Artikel ilmiah: Dana Desa: Alokasi Dan Potensi Inefektivitasnya. Jakarta.

${ }^{6}$ Peraturan Menteri Desa, Pembangunan Daerah Tertinggal, dan Transmigrasi Nomor 05 tahun 2015 tentang Penetapan Prioritas Penggunaan Dana Desa Tahun 2015, Pasal 3.

$7 \underline{I B I D} .$, Pasal 5.

Muhammad Eko Atmojo, Helen Dian Fridayani, Aulia Nur Kasiwi, Mardha Adhi Pratama/Dana Desa/ 7/Vol. 5. No. 1. Tahun 2017 


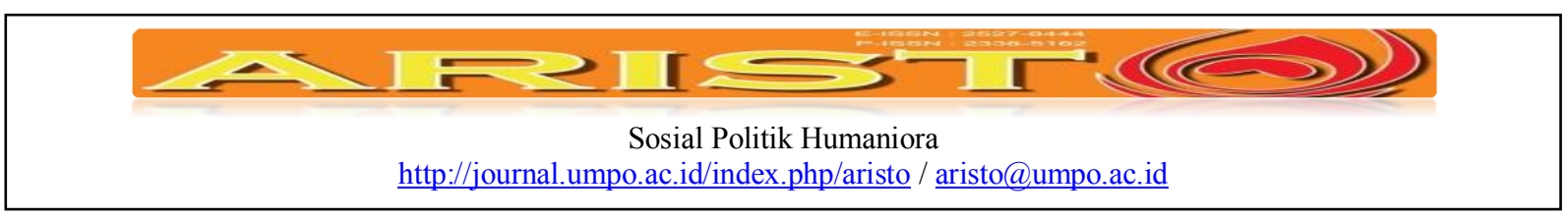

gabungan desa yang diantaranya Paitan, Sribitan, Bangen dan Kasongan. Dari banyaknya desa yang mempunyai sektor ekonomi berbasis masyarakat maka dapat disimpulkan bahwasannya Desa Bangunjiwo mempunyai potensi ekonomi yang tinggi. Dari banyaknya desa yang mempunyai kerajinan, hanya Desa Bangujiwo yang memiliki potensi ekonomi yang sangat tinggi. Salah satunya dusun yang mempunyai potensi ekonomi berbasis masyarakat tinggi adalah dusun Kasongan dimana dusun ini terkenal dengan kerajinan grabah atau keramik. Kerajinan grabah dari Kasongan terkenal di dalam maupun luar negeri. Selain itu potensi ekonomi yang diserap masyarakat sampai saat ini masih banyak lagi, diantaranya terdapat kerajinan lain seperti Batu di Lemahdadi, Wayang Kulit di Gendeng, Kerajinan Bambu di Jipangan yang dikemas menjadi potensi unggulan yaitu: "KAJIGELEM". Banyaknya potensi ekonomi yang ada maka Desa Bangunjiwo dalam meningkatan perekonomian dan pemberdayaan selalu melibatkan masyarakat. Dari data yang telah dipaparkan di atas maka penelitian ini berusaha untuk mengetahui dan menganalisa efekitvitas dana desa untuk pengembangan potensi ekonomi yang berbasis partisipasi masyarakat di Desa Bangunjiwo.

\section{Metode}

Penelitian ini menggunakan metode atau pendekatan kualitatif. Metode penelitian kualitatif biasanya disebut juga dengan metode penelitian naturalistic, karena penelitiannya dilakukan pada kondisi yang alamiah (natural setting), disebut juga dengan metode kualitatif karena data yang terkumpul dan analisisnya lebih bersifat kualitatif. ${ }^{8}$ Penelitian ini akan dilaksanakan di Pemerintah Desa dan Masyarakat Desa Bangunjiwo Kabupaten Bantul Daerah Istimewa Yogyakarta. Teknik pengumpulan data pada penelitian ini menggunakan observasi, wawancara, dan dokumentasi. Analisis data dalam penelitian ini menggunakan metode analisis oleh Milles dan Huberman dalam Sugiono yang terdiri dari 3 macam diantaranya adalah reduksi data, penyajian data dan penarikan kesimpulan. ${ }^{9}$

\footnotetext{
${ }^{8}$ Sugiyono, 2014. Metode Penelitian Kuantitatif, Kualitatif dan R\&D. Alfabeta, Bandung

${ }^{9} \underline{I B I D}$
} 


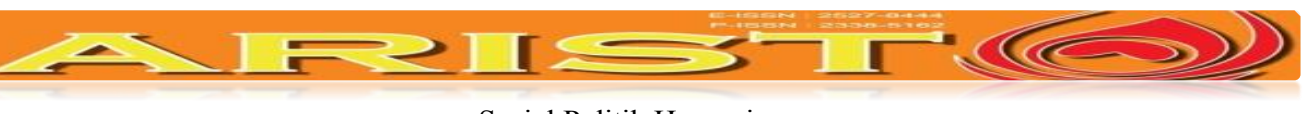

Sosial Politik Humaniora

http://journal.umpo.ac.id/index.php/aristo / aristo@umpo.ac.id

\section{Hasil dan Pembahasan}

\section{Efektifitas Dana Desa}

Otonomi daerah dirasa lebih efektif untuk membangun sebuah daerah, dengan adanya otonomi daerah maka pembangunan suatu daerah dapat berjalan dengan baik, karena pembangunan infrastruktur akan lebih merata dan dapat dirasakan langsung oleh masyarakat. Begitu juga dengan desa, dimana setelah adanya UU No 6 Tahun 2014 tentang Desa, maka desa diberi kewenangan untuk mengurus urusan rumah tangganya, terutama dalam hal pengelolaan dana desa. Tujuan pemberian dana desa adalah untuk pemerataan pembangunan infrastruktur disetiap desa, sehingga pembangunan bukan dikendalikan pada tingkat kabupaten/kota saja.

Dana desa sangat membantu pemerintah desa untuk mewujudkan kebijakan dan pembangunan infrastruktur serta dapat mensejahterakan masyarakat desa yang masih jauh dari kata sejahtera bagi pemerintah pusat. Masyarakat desa secara khusus perlu diberikan perhatian khusus, terutama pada masalah-masalah yang menghambat proses perubahan masyarakat desa dalam pembangunan nasional. Adanya dana desa bisa memberi harapan yang terbuka bagi masyarakat untuk mengembangkan dan memajukan desa, terutama dalam bidang ekonomi berbasis masyarakat. Dimana dengan adanya dana desa masyarakat bisa bertahan hidup dengan mengikuti perkembangan zaman terutama dalam hal ekonomi berbasis masyarakat.

Pemanfaatan dana desa untuk pembangunan dan perkembangan desa dapat didukung oleh beberapa faktor. Sujiono menyatakan ada beberapa faktor-faktor yang dapat mempengaruhi tingkat dan arah perkembangan desa adalah faktor lokasi, fasilitas daerah dan infrastruktur diantaranya jalan penghubung. ${ }^{10}$ Dengan adanya dana desa maka faktor-faktor yang bisa mempengaruhi perkembangan desa setidaknya bisa diminimalisir, sehingga perkembangan desa bisa berjalan sesuai dengan rencana atau berkembang dengan baik. Sebelum adanya dana desa, perubahan-perubahan yang ada di dalam masyarakat sangat lambat terutama yang disebabkan oleh pendapatan rendah, pendidikan kurang memadai, dan juga status pekerjaan yang jauh dibatas normal.

Setelah adanya pendayagunaan dana desa, prioritas tersebut menggutamakan untuk mendanai program atau kegiatan bidang pelaksanaan pembangunan desa dan pemberdayaan masyarakat desa. Hal ini telah diatur dalam Permendes yang mana "Dana desa diprioritaskan

${ }^{10}$ Sujiono. P. 2006. Manajemen Pelayanan Publik. Cendekia. Jakarta hal. 235 


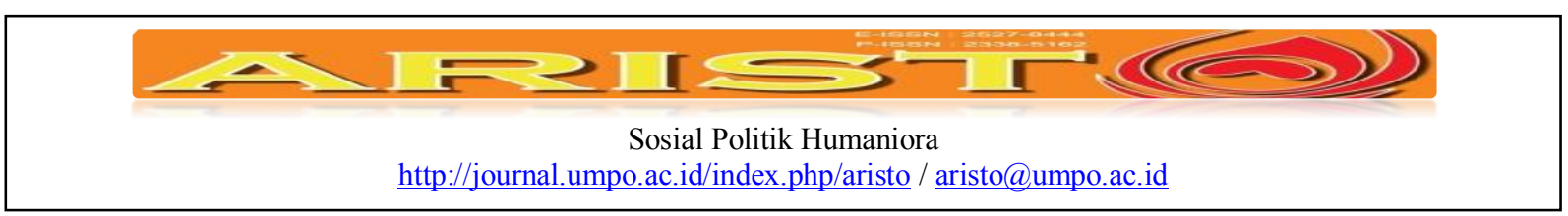

untuk membiayai pelaksanaan program dan kegiatan berskala lokal desa dibidang Pembangunan Desa dan Pemberdayaan Masyarakat Desa". ${ }^{11}$ Terbukti bahwa pada tahun 2015 setelah adanya dana desa, jumlah penduduk usia 18-56 tahun yang bekerja tidak tentu kini menjadi 523 orang saja dibanding tahun sebelumnya sebanyak 4978 orang, dengan kata lain penduduk yang bekerja tidak tentu turun drastis sebesar $89 \%$ atau berkurang 4.455 orang. Bukti kedua, jumlah keluarga prasejahtera yang awalnya sbanyak 3271 keluarga, setelah adanya dana desa turun menjadi 1338 keluarga saja. ${ }^{12}$ Dana desa yang dimanfaatkan oleh Pemerintah Desa dengan baik maka akan sangat efektif untuk pembangunan desa, terutama dalam hal pengentasan kemiskinan dan pengembangan masyarakat.

Prioritas penggunaan Dana Desa didasarkan pada prinsip-prinsip: pertama, keadilan, dengan menggutamakan hak atau kepentingan seluruh warga desa tanpa membeda-bedakan. Kedua, kebutuhan prioritas, dengan mendahulukan kepentingan desa yang lebih mendesak. Ketiga, tipologi desa, dengan mempertimbangkan keadaan dan kenyataan karakteristik geografis, sosiologis, antropologis, ekonomi dan ekologi desa yang khas, serta perubahan atau perkembangan kemajuan desa. ${ }^{13}$

\section{Pemberdayaan Masyarakat}

Desa Bangunjiwo telah menggunakan dana desa untuk pemberdayaan masyarakat desa, yang khususnya pada pengembangan potensi ekonomi bagi masyarakat. Hal ini dibuktikan dengan adanya potensi ekonomi dan pariwisata yang cukup besar yang bisa dikembangkan di Desa Bangujiwo, yaitu berupa sentra kerajinan gerabah di Kasongan. Akan tetapi, sentra kerajinan yang berada di Desa Bangunjiwo bukan hanya kerajinan grabah melainkan ada beberapa sentra kerajinan lain yang berada di Desa Bangunjiwo diantaranya seperti sentra kerajinan bambu Jipangan, kemudian ada Lemahdadi dengan kerajinan Patung Batu-nya, dan seni tatah sungging kulit yang terdapat di Gendeng. Dimana pariwisata unggulan Desa

${ }^{11}$ Peraturan Menteri Desa, Pembangunan Daerah Tertinggal, dan Transmigrasi, No 21 tahun 2015 tentang Penetapan Prioritas Penggunaan Dana Desa Tahun 2016, Pasal 4.

${ }^{12}$ Daftar Isian Tingkat Perkembangan Desa dan Kelurahan pada Tahun 2015. Desa Bangunjiwo.

${ }^{13}$ Peraturan Menteri Desa, Pembangunan Daerah Tertinggal, dan Transmigrasi, No 21 tahun 2015 tentang Penetapan Prioritas Penggunaan Dana Desa tahun 2016, Pasal 3.

Muhammad Eko Atmojo, Helen Dian Fridayani, Aulia Nur Kasiwi, Mardha Adhi Pratama/Dana Desa/ 7/Vol. 5. No. 1. Tahun 2017 


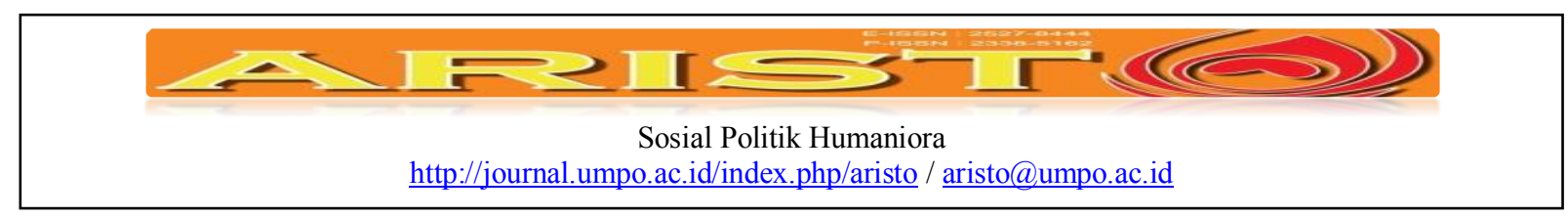

Bangunjiwo terletak pada bidang industri kerajinan tersebut yang dirangkum dalam satu paket bernama "KAJIGELEM". Kajigelem merupakan singkatan dari Kasongan, Jipangan, Gendeng dan Lemahdadi, yang mana keempatnya merupakan sentra industri kerajinan yang paling menonjol di Bangunjiwo.

Kajigelem, yang merupakan singkatan dari Kasongan, Jipangan, Gendeng, dan Lemah Dadi merupakan centra industri yang sudah terkenal di Desa Bangunjiwo. Keempat daerah tersebut menjadi pusat perhatian wisatawan baik dalam negeri maupun luar negeri, hal ini tidak terlepas dari adanya bantuan dana desa yang digunakan untuk pengembangan masyarakat. ${ }^{14}$ Bentuk Pengembangan masyarakat yang diinginkan yaitu baik berupa pemberian bantuan alat maupun pelatihan yang diberikan kepada masyarakat yang memerlukannya. Desa Bangujiwo mendapatkan bantuan dana desa yang cukup besar, dimana dengan adanya dana desa maka banyak sekali perubahan yang terjadi di desa tersebut, diantaranya adalah infrastruktur yang memadai, tingkat pekerjaan yang diperoleh masyarakat jauh lebih baik. Basis ekonomi di Desa Bangunjiwo itu sendiri mempunyai dampak yang sangat positif baik dari sisi pendapatan dan wisatawan yang mengunjungi daerah tersebut yang sekarang disebutkan dengan ciri khas home industry. $^{15}$

Bentuk pemberdayaan masyarakat yang lainnya berupa fasilitasi paralegal untuk memberikan bantuan hukum kepada warga masyarakat desa misalnya dengan cara kemudahan pemberian ijin usaha kepada warga pribumi Desa Bangunjiwo bila ingin membuka usaha di desanya sendiri. Pemerintah Desa Bangunjiwo sangat mendukung kepada warganya yang aktif untuk membuka usaha diantaranya dibidang perdagangan, pengrajin seni, home industry, dan lain-lain, karena desa ingin memberdayakan masyarakatnya sendiri yang ingin bekerja di desanya sendiri. ${ }^{16}$ Bukti lain dari Desa Bangunjiwo adalah pemberdayaan masyarakat, hal ini dapat dilihat dari aktifnya paguyuban-paguyuban yang terdapat di padukuhan-padukuhan, kumpulan golongan pekerja, dan lain-lain. Konkritnya Desa Bangunjiwo memiliki organisasi anggota lembaga kemasyarakatan desa termasuk RT, RW, PKK, LKMD/K, LPM, Karang

\footnotetext{
${ }^{14}$ Daftar Isian Tingkat Perkembangan Desa dan Kelurahan pada Tahun 2015. Desa Bangunjiwo.

${ }^{15}$ Daftar Isian Tingkat Perkembangan Desa dan Klurahan pada Tahun 2015. Desa Bangunjiwo.

${ }^{16} \underline{I B I D}$
}

Muhammad Eko Atmojo, Helen Dian Fridayani, Aulia Nur Kasiwi, Mardha Adhi Pratama/Dana Desa/ 7/Vol. 5. No. 1. Tahun 2017 


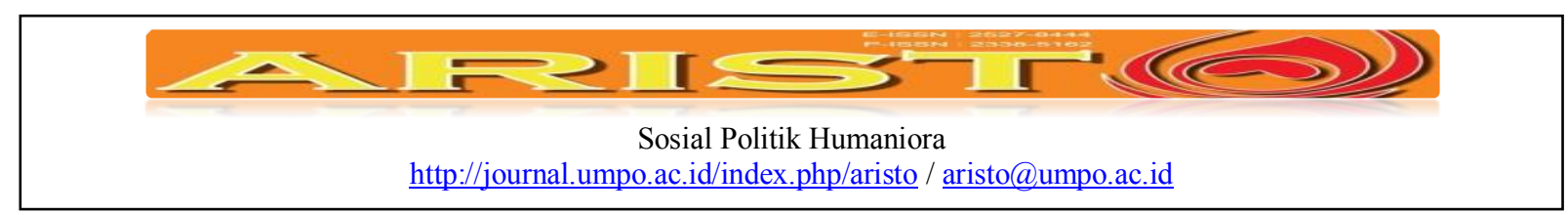

Taruna, Bumdes, Lembaga Adat, Kelompok Tani dan lembaga lainnya sebanyak 5 unit organisasi. Dan setiap tahunnya masing-masing organisasi anggota lembaga kemasyarakatan desa diberikan dana 5 juta untuk operasional organisasi. ${ }^{17}$

Sesuai dengan amanat PermenDes Nomor 5 tahun 2014, pemberdayaan masyarakat juga harus memenuhi kebutuhan sarana dan prasarana supaya masyarakat semakin terfasilitasi dengan baik. Selain itu pemberdayaan dapat berupa ide dan gagasan yakni kemampuan mengekspresikan dan menyumbangkan gagasan dalam suatu forum atau diskusi secara bebas dan tanpa tekanan. ${ }^{18}$ Misalnya, membuat ide atau gagasan tentang BUMDesa demi memajukan perekonomian desa, ide untuk memperbaiki infrastruktur desa seperti jalan desa, jalan usaha tani, sanitasi lingkungan, air bersih berskala desa, serta sarana dan prasarana produksi di desa. Pemberdayaan masyarakat ini akan terlihat ketika aktifitas ekonomi berjalan dengan lancar atau tersendat. Aktifitas ekonomi inilah yang nantinya akan memberikan feedback kepada pemberdayaan masyarakat desa.

\section{Pengembangan Potensi Ekonomi}

Masyarakat desa sangat membutuhkan pemberdayaan dengan alasan sebagai upaya untuk mengembangkan kemandirian dan tingkat meratanya kesejahteraan masyarakat dengan cara meningkatkan pengetahuan, keterampilan, kemampuan serta memanfaatkan sumberdaya melalui kebijakan, program, kegiatan maupun pendampingan yang sesuai dengan esensi masalah dan prioritas kebutuhan masyarakat desa. ${ }^{19}$ Desa Bangunjiwo yang sebagian besar masyarakatnya adalah pengusaha rumahan sangat tepat untuk dilakukan pemberdayaan maupun pengembangan potensi ekonomi. Tidak hanya bentuk industri saja yang sangat efektif dalam pengembangan masyarakat, tetapi dari segi pekerjaan masyarakat Desa Bangujiwo tidak perlu keluar daerah untuk mendapatkan pekerjaan. Dengan begitu maka pemerintah desa perlu mendukung terwujudnya pemberdayaan dan pengembangan ekonomi berbasis masyarakat di Desa Bangunjiwo. Dengan adanya dukungan pemerintah desa maupun pemerintah daerah maka

\section{${ }^{17} \underline{I B I D}$} Development.

18 Wahjudin, Sumpeno 2011. Perencanaan Desa Terpadu. Banda Aceh,Reinforcement Action and

${ }^{19}$ Desleani, Andaria. 2011, Pengembangan Masyarakat Desa Melalui Dana Desa, Gramedia. Jakarta 


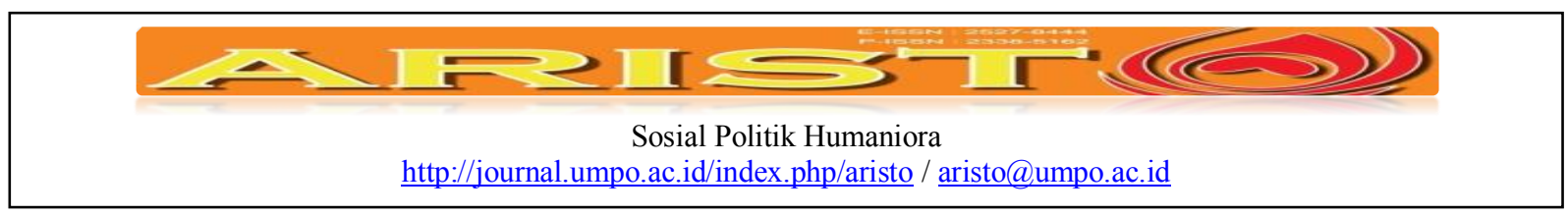

pemberdayaan maupun pengembangan ekonomi di Desa Bangujiwo akan semakin meningkat tajam.

Salah satu indikator untuk meningkatkan potensi ekonomi lokal adalah dengan membuat desa wisata. Desa Bangunjiwo salah satu desa di Kabupaten Bantul yang memiliki desa wisata yaitu KAJIGELEM, maka desa-desa wisata tersebut bisa meningkatkan potensi ekonomi bagi desa maupaun daerah. Untuk mengenalkan Desa Bangujiwo kepada khalayak umum sebagai desa wisata maka dapat menggunakan media elektronik maupun media cetak, misalnya mempublish desa wisata yang ada di Desa Bangujiwo di media sosial, website pemerintah desa atau website Dinas Pariwisata Kabupaten Bantul dan lain-lain. Demi mempertahankan eksistensi kerajinan grabah dan lain-lain Pemerintah Desa Bangunjiwo juga harus memperhatikan manajemen pengelolaan dan pemasaran hasil kerajinan, dengan adanya perhatian dari pemerintah maka eksistensi kerajinan di Desa Bangujiwo akan semakin dapat dipertahankan.

Pengembangan potensi ekonomi ini dapat dilakukan juga melalui perluasan distribusi penjualan, misalnya penjualan hasil kerajinan masyarakat Desa Bangujiwo ke luar negeri. Hal ini bukan hal yang mustahil dilakukan oleh Pemerintah Desa Bangunjiwo maupun Pemerintah Kabupaten Bantul, berdasarkan perkembangan ekspor dari Dinas Perindakop Kabupaten Bantul hampir setiap tahunnya meningkat. Peningkatan daya ekspor Daerah Kabupaten Bantul sangat luar biasa pada tahun 2013 nilai ekspor (US\$) sebesar 56.644.456,97, sedangkan pada tahun 2014 nilai ekspor (US\$) sebesar 60,099,768.85. ${ }^{20}$ Salah satu penyumbang volume dan nilai ekspor tertinggi terdapat di Desa Bangunjiwo.Artinya bila ekspor terus ditingkatkan, maka potensi ekonomi akan semakin meningkat, penyerapan tenaga kerja juga akan semakin banyak dan angka pengangguran serta angka kemiskinan dapat ditekan.

\section{Partisipasi Masyarakat}

Penggunaa dana desa, harus melibatkan masyarakat secara luas, karena dalam penggunaan dana desa kebutuhan dan sikap masyarakat menjadi sangat penting, terutama pada tingkat partisipasi masyarakat. Adanya pelibatan peran masyarakat dalam penggunaan dana desa mempunyai pengaruh besar, dimana pemerintah mendapatkan keuntungan dari sisi akuntabilitas

${ }^{20}$ www.perindagkop.bantulkab.go.id Laporan AKuntabilitas Kinerja Pemerintah (LAKIP) Tahun 2014 http://perindagkop.bantulkab.go.id/filestorage/dokumen/2016/10/disperindagkop_lakip_2014.pdf diakses pada tanggal 20 Februari 2017, pukul 17.00 WIB

Muhammad Eko Atmojo, Helen Dian Fridayani, Aulia Nur Kasiwi, Mardha Adhi Pratama/Dana Desa/ 7/Vol. 5. No. 1. Tahun 2017 


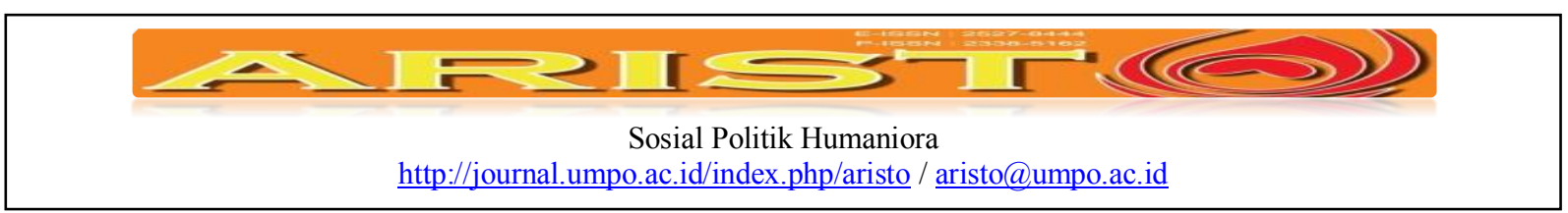

penggunaan dana desa sebab penggunaan dana desa bisa menjadi lebih baik. Sedangkan disisi masyarakat, sangat bermanfaat dan menguntungkan apabila mereka aktif berpartisispasi karena sesungguhnya program ini untuk kesejahteraan masyarakat, semakin aktif masyarakat maka semakin terpenuhi kebutuhannya.

Pemerintah Desa Bangunjiwo sudah melibatkan masyarakat dalam mengembangkan potensi ekonomi di daerahnya sendiri. Hal itu didukung oleh dana desa yang tersalurkan kepada masyarakat, yang mana masyarakat mampu menerima dan mampu ikut serta dalam berpartisipasi untuk mengembangkan potensi ekonomi di desa tersebut. Pertama, pada saat perencanaan kegiatan dan anggaran. Masyarakat aktif dalam kegiatan musyawarah perencanaan dan pembangunan pada tingkat desa. Hal ini dapat dibuktikan dengan tingkat partisipasi musrenbang masyarakat Desa Bangujiwo yang sangat baik. Berikut adalah tabel perbandingan partisipasi masyarakat dalam musrenbang tahun 2014 dan 2015.

\section{Tabel 1}

Partisipasi Masyarakat Dalam Perencanaan Tahun 2014-2015

\begin{tabular}{|c|c|c|}
\hline Peranserta Masyarakat dalam Perencanaan Pembangunan & 2014 & 2015 \\
\hline $\begin{array}{l}\text { Jumlah musyawarah perencanaan pembangunan tingkat Desa/Kelurahan yang } \\
\text { dilakukan pada tahun ini, termasuk di tingkat dusun dan lingkungan }\end{array}$ & 5 kali & 10 kali \\
\hline $\begin{array}{l}\text { Jumlah kehadiran masyarakat dalam setiap kali musyawarah tingkat dusun/lingkungan } \\
\text { dan desa/kelurahan }\end{array}$ & $95 \%$ & $96,5 \%$ \\
\hline $\begin{array}{l}\text { Penggunaan Profil Desa/Kelurahan sebagai sumber data dasar yang digunakan dalam } \\
\text { perencanaan pembangunan desa dan Forum Musrenbang Partisipatif }\end{array}$ & Ya & $\mathrm{Ya}$ \\
\hline $\begin{array}{l}\text { Pelibatan masyarakat dalam pemutakhiran data profil desa dan kelurahan sebagai } \\
\text { bahan dalam Musrenbang partisipatif }\end{array}$ & Ya & Ya \\
\hline Usulan masyarakat yang disetujui menjadi Rencana Kerja Desa dan Kelurahan & $95 \%$ & $96 \%$ \\
\hline $\begin{array}{l}\text { Usulan Pemerintah Desa dan Kelurahan yang disetujui menjadi Rencana Kerja } \\
\text { Desa/Kelurahan dan dimuat dalam RAPB-Desa }\end{array}$ & $90 \%$ & $92 \%$ \\
\hline $\begin{array}{l}\text { Usulan rencana kerja program dan kegiatan dari pemerintah kabupaten/kota/provinsi } \\
\text { dan pusat yang dibahas saat Musrenbang dan disetujui untuk dilaksanakan di desa dan } \\
\text { kelurahan oleh masyarakat dan lembaga kemasyarakatan desa/kelurahan }\end{array}$ & $90 \%$ & $90 \%$ \\
\hline
\end{tabular}

Sumber: Daftar Isian Tingkat Perkembangan Desa dan Kelurahan Desa Bangunjiwo

Pada tahun 2014, musyawarah perencanaan pembangunan tingkat desa/kelurahan, dusun/lingkungan telah dilakukan sebanyak 5 kali dan jumlah kehadiran masyarakat dalam setiap kali musyawarah tingkat dusun/lingkungan dan desa/kelurahan sebanyak 95\%. Hasilnya adalah usulan masyarakat yang disetujui menjadi Rencana Kerja Desa atau Kelurahan sebesar 95\% dan Usulan Pemerintah Desa yang disetujui menjadi Rencana Kerja Desa/Kelurahan dan 


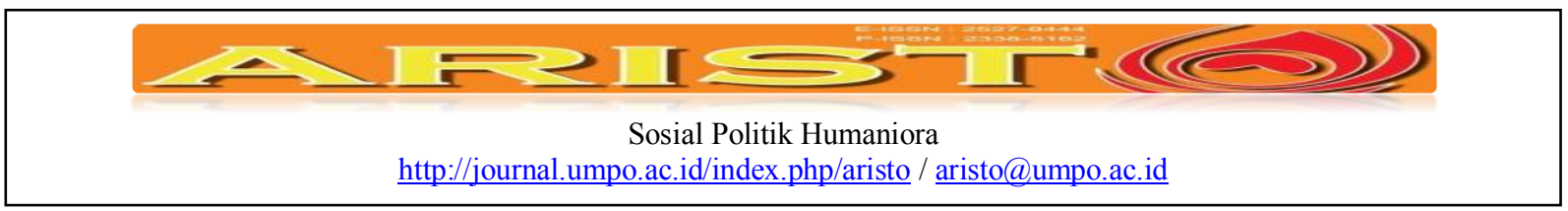

dimuat dalam RAPB-Desa sebanyak 90\%. ${ }^{21}$ Kemudian pada tahun 2015 meningkat, jumlah musyawarah perencanaan pembangunan tingkat desa/kelurahan di intensifkan menjadi 10 kali dan jumlah kehadiran masyarakat dalam setiap kali musyawarah tingkat dusun/lingkungan dan desa/kelurahan sebanyak 96,5\%. Hasilnya adalah usulan masyarakat yang disetujui menjadi Rencana Kerja Desa atau Kelurahan sebanyak 96\% dan Usulan Pemerintah Desa yang disetujui menjadi Rencana Kerja Desa/Kelurahan dan dimuat dalam RAPB-Desa sebesar 92\%. ${ }^{22}$ Data tersebut menunjukkan bahwa dengan adanya dana desa partisipasi masyarakat Desa Bangujiwo sangat meningkat. Kedua, pada saat pelaksanaan program. Peran masyarakat dalam pelaksanaan program atau kegiatan pembangunan desa sangat diperlukan, karena dengan dukungan masyarakat program dan kegiatan yang telah ditetapkan dapat berjalan dengan baik. Selain itu masyarakatlah yang nantinya akan menjaga maupun melestarikan hasil pembangunan tersebut. Desa Bangunjiwo memiliki presentasi yang tidak mengalami perubahan yang signifikan, hal ini dapat dilihat pada tabel berikut ini:

\section{Tabel 2}

\section{Partisipasi Masyarakat Dalam Pelaksanaan Tahun 201-2015}

\begin{tabular}{|c|c|c|}
\hline $\begin{array}{c}\text { Peranserta masyarakat dalam Pelaksanaan dan Pelestarian Hasil } \\
\text { Pembangunan }\end{array}$ & 2014 & 2015 \\
\hline $\begin{array}{l}\text { Jumlah masyarakat yang terlibat dalam pelaksanaan pembangunan fisik di } \\
\text { desa dan kelurahan sesuai hasil Musrenbang }\end{array}$ & 1926 orang & 1926 orang \\
\hline $\begin{array}{l}\text { Jumlah penduduk yang dilibatkan dalam pelaksanaan proyek padat karya oleh } \\
\text { pengelola proyek yang ditunjuk pemerintah desa/kelurahan atau } \\
\text { kabupaten/kota }\end{array}$ & 165 orang & 165 orang \\
\hline $\begin{array}{l}\text { Jumlah kegiatan yang dilaksanakan oleh masyarakat dan lembaga } \\
\text { kemasyarakatan desa/kelurahan yang sudah ada sesuai ketetapan dalam APB- } \\
\text { Desa }\end{array}$ & 15 kegiatan & 45 kegiatan \\
\hline $\begin{array}{l}\text { Pelaksanaan kegiatan dari masyarakat untuk menyelesaikan atau } \\
\text { menindaklanjuti kegiatan yang belum diselesaikan oleh pelaksana } \\
\text { sebelumnya. }\end{array}$ & Ada & ada \\
\hline $\begin{array}{l}\text { Jumlah kegiatan yang didanai dari APB-Desa dan swadaya masyarakat di } \\
\text { kelurahan }\end{array}$ & 5 kegiatan & 5 kegiatan \\
\hline $\begin{array}{l}\text { Jumlah kegiatan di desa dan kelurahan yang didanai dari APB Daerah } \\
\text { Kabupaten/Kota }\end{array}$ & 10 kegiatan & 10 kegiatan \\
\hline Jumlah kegiatan di desa dan kelurahan yang didanai dari APBD Provinsi & 5 kegiatan & 5 kegiatan \\
\hline Jumlah kegiatan di desa dan kelurahan yang didanai APBN & 5 kegiatan & 5 kegiatan \\
\hline
\end{tabular}

Sumber: Daftar Isian Tingkat Perkembangan Desa dan Klurahan Desa Bangunjiwo

\footnotetext{
${ }^{21}$ Daftar Isian Tingkat Perkembangan Desa dan Klurahan pada Tahun 2014. Desa Bangunjiwo

22 Daftar Isian Tingkat Perkembangan Desa dan Klurahan pada Tahun 2015. Desa Bangunjiwo
} 


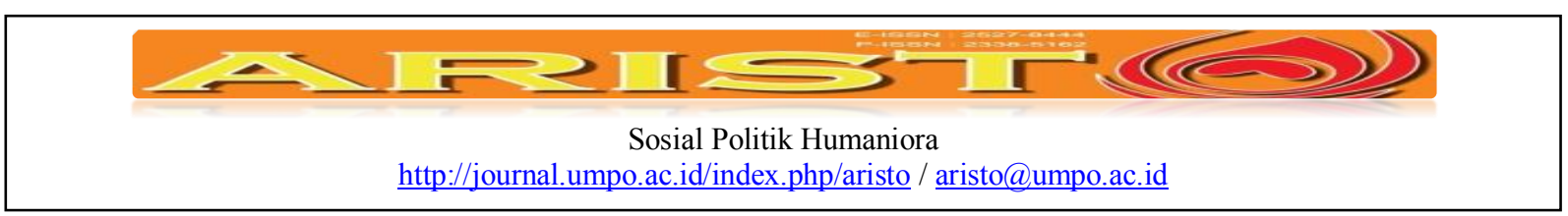

Perubahan aktivitas partisipasi masyarakat dalam pelaksanaan dan pelestarian hasil pembangunanan hanya terlihat pada kegiatan yang dilaksanakan oleh masyarakat dan lembaga kemasyarakatan desa/kelurahan. Program/kegiatan ini sudah sesuai dengan ketetapan dalam APB-Desa dari 15 kegiatan menjadi 45 kegiatan. Dengan adanya penambahan program/kegiatan dari tahun 2014 ke tahun 2015 maka pemerintah telah memberikan ruang yang lebih besar kepada masyarakat untuk meningkatkan partisispasi dan mengembangkan ekonomi berbasis masyarakat.

Ketiga, proses monitoring dan evaluasi. Monitoring dan evaluasi wajib dilakukan oleh pemerintah hal ini untuk melihat realisasi program/kegiatan yang sudah direncanaan. Selain itu pemerintah juga wajib memberikan laporan pertanggung jawaban atas program dan kegiatan beserta anggaran yang digunakan setiap akhir tahun. Laporan itu ditujukan secara transparan kepada masyarakat desa yang nantinya akan diserahan kepada kepala daerah. Pada implementasinya Pemerintah Desa Bangunjiwo sudah melaksanakannya dengan baik, karena setiap tahun pemerintah desa selalu megadakan pelaporan kegiatan kepada masyarakat paling lambat dibulan terakhir tahun anggaran. Selain itu Pemerintah Desa Bangunjiwo juga mempublish proses yang dilakukan selama setahun yang dimulai dari perencanaan hingga evaluasi, dan sejauh ini masyarakat Bangunjiwo memiliki antusias yang tinggi dan selalu menerima laporan pertanggungjawaban Pemerintah Desa. Maka dapat disimpulkan bahwa dengan adanya dana desa partisipasi masyarakat di Desa Bangunjiwo sangat tinggi sehingga pemberdayaan dan potensi ekonomi berbasis masyarakat bisa dijalankan dengan baik, hal ini juga didukung dengan transparansi pertanggungjawaban kegiatan setiap tahunnya.

\section{Kesimpulan}

Dana Desa adalah dana yang bersumber dari Anggaran Pendapatan dan Belanja Negara yang diperuntukkan bagi desa yang ditransfer melalui Anggaran Pendapatan dan Belanja Daerah Kabupaten/Kota dan digunakan untuk mendanai penyelenggaraan pemerintahan, pelaksanaan pembangunan, pembinaan kemasyarakatan, dan pemberdayaan masyarakat. Penggunaan dana desa di Desa Bangujiwo sangat efektif terutama pada pengembangan ekonomi desa untuk memberdayakan masyarakat yang pada akhirnya dapat membantu meningkatkan ekonomi di Desa Bangunjiwo. Peran serta atau inisiatif dari pemerintah desa juga sangat penting dalam 


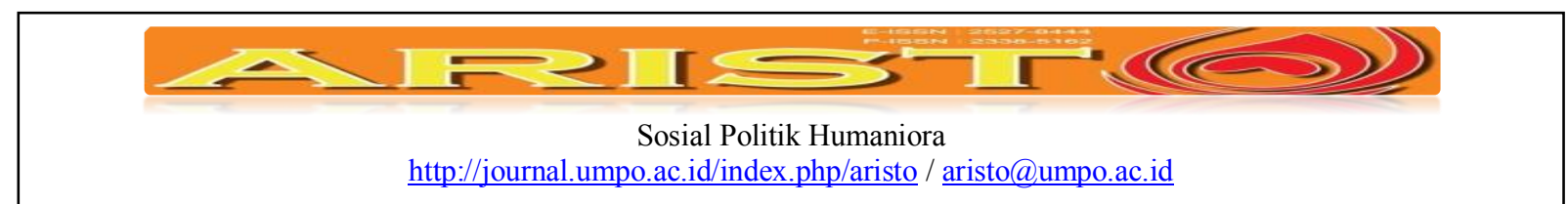

rangka pemberdayaan masyarakat desa karena wewenang utama pemerintah desa ada pada perencanaan. Pada proses perencanaan pembangunan masyarakat Desa Bangujiwo selalu aktif ikut berpartisipasi terutama pada kegiatan musrenbang sehingga pemberdayaan masyarakat bisa berjalan dengan baik. Hal ini dibuktikan dengan kehadiran masyarakat yang ikut dalam musyawarah perencanaan pembangunan tingkat desa/kelurahan sebanyak 95\% pada tahun 2014 dan 96,5\% pada tahun 2015. Maka dapat disimpulkan bahwa pemberdayaan masyarakat memang tak lepas dari dibutuhkannya partisipasi masyarakat yang ikut serta aktif dalam pembangunan desa yang mulai dari perencanaan yaitu musrenbang, pelaksanaan yaitu masyarakat aktif dalam memberikan usulan pengadaan dan produktivitas desa, dan juga evaluasi yaitu masyarakat aktif adalam hal pengawasan program pemerintah desa dan juga memberikan masukan, kritikan bahkan solusi guna menciptakan program yang lebih baik lagi. 


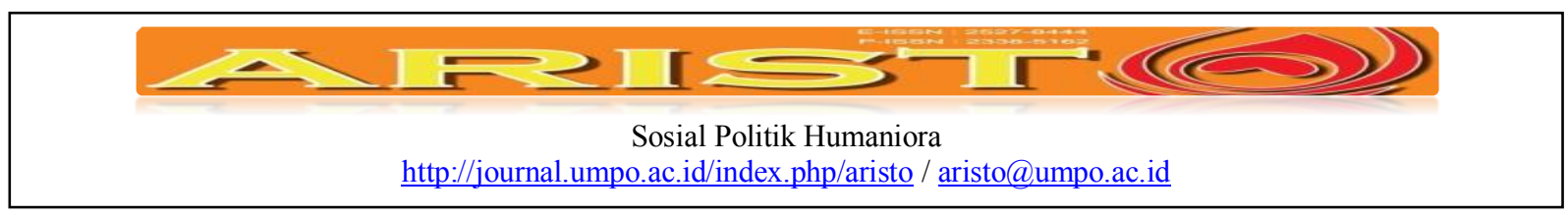

\section{Daftar Pustaka}

Desleani, Andaria. (2011). Pengembangan Masyarakat Desa Melalui Dana Desa. Jakarta: Gramedia.

Putra, Chandra Kusuma dkk. (2013). Pengelolaan Alokasi Dana Desa Dalam Pemberdayaan Masyarakat Desa (Studi Pada Desa Wonorejo Kecamatan Singosari Kabupaten Malang). Jurnal Administrasi Publik Vol. 1 No 6.

Sugiyono, (2014). Metode Penelitian Kuantitatif, Kualitatif dan R\&D. Bandung: Alfabeta.

Sujiono. P. (2006). Manajemen Pelayanan Publik. Jakarta: Cendekia.

Wahjudin, Sumpeno. (2011). Perencanaan Desa Terpadu. Banda Aceh, Reinforcement Action and Development

\section{Artikel Ilmiah:}

Biro Analisa Anggaran dan Pelaksanaan APBN - SETJEN DPR RI. Artikel ilmiah: Dana Desa: Alokasi Dan Potensi Inefektivitasnya. Jakarta

\section{Produk Hukum:}

Undang-Undang Nomor 6 Tahun 2014 tentang Desa

Daftar Isian Tingkat Perkembangan Desa dan Kelurahan pada Tahun 2014. Desa Bangunjiwo

Daftar Isian Tingkat Perkembangan Desa dan Kelurahan pada Tahun 2015. Desa Bangunjiwo

Peraturan Menteri Desa, Pembangunan Daerah Tertinggal, dan Transmigrasi Nomor 05 tahun 2015 tentang Penetapan Prioritas Penggunaan Dana Desa Tahun 2015. Jakarta: Lembaran Negara

Peraturan Menteri Desa, Pembangunan Daerah Tertinggal, dan Transmigrasi, No 21 tahun 2015 tentang Penetapan Prioritas Penggunaan Dana Desa Tahun 2016.

\section{Website:}

Badan Pusat Statistik. (2013). Jumlah Penduduk Miskin dan Prosentase Penduduk Miskin di Indonesia. Diperoleh di http://www.bps.go.id/.

www.pendagkop.bantulkab.go.id Laporan Akuntabilitas Kinerja Pemerintah (LAKIP) tahun 2014.http://perindagkop.bantulkab.go.id/filestorage/dokumen/2016/10/disperindagkop_laki p_2014.pdf

Pertumbuhan Ekonomi tak Merata, Pengamat: Akibat Ketimpangan Infrastruktur diakses dari http://www.republika.co.id/berita/ekonomi/makro/15/05/07/nny3e7-pertumbuhan- 


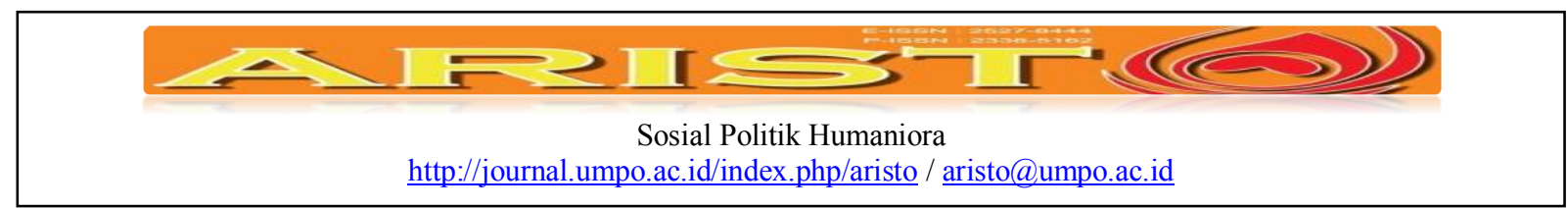

ekonomi-tak-merata-pengamat-akibat-ketimpangan-infrastruktur pada tanggal 17 April 2017, pukul 09.30 WIB. 